\title{
CHAPTER 33
}

\section{MACROECONOMIC POLICIES AND EXCHANGE RATE MATTERS}

\section{Article 33.1: Definitions}

For the purposes of this Chapter:

Article IV Staff Report means the report prepared by a staff team of the International Monetary Fund (IMF) for consideration by the Executive Board of the IMF in the context of a country's adherence to Article IV, Section 3(b), of the IMF Articles of Agreement;

competitive devaluation means an action undertaken by an exchange rate authority of a Party for the purpose of preventing effective balance of payments adjustment or gaining an unfair competitive advantage in trade over another Party;

Currency Composition of Official Foreign Exchange Reserves (COFER) database means the IMF database based on voluntary and confidential participation by IMF member countries, which distinguishes monetary authorities' claims on non-residents denominated in U.S. dollars, euros, pounds sterling, Japanese yen, Swiss francs, and other currencies on a quarterly basis starting in 2005;

exchange rate means the price of one currency in terms of another currency;

exchange rate assessment means the IMF staff's evaluation of a country's exchange rate as presented to the IMF Executive Board as part of a Party's Article IV consultation or as published in the annual External Sector Report, consistent with recommendation 4 in the IMF 2011 Triennial Surveillance Review - Overview Paper, prepared on August 29, 2011;

Executive Board discussion means the discussion by the IMF Executive Board of the Party's Article IV Staff Report leading to the conclusion of the Article IV consultation, as defined in Paragraph 27 in Part III Section A of the Modernizing the Legal Framework for Surveillance-An Integrated Surveillance Decision, Revised Proposed Decisions, prepared on July 17, 2012;

exports means all goods that subtract from the stock of material resources of a country by leaving its economic territory (International Merchandise Trade Statistics: Concepts and Definitions 2010, Chapter I, section A 1.2 of the United Nations);

foreign exchange means the official currency of another Party or a non-Party;

foreign exchange market means a market, wherever located, in which participants can purchase or sell foreign exchange; 
foreign exchange reserves means claims of an exchange rate authority or monetary authority on nonresidents in the form of foreign banknotes, bank deposits, treasury bills, short- and long-term government securities, and other claims usable in the event of balance of payments need, as defined in the IMF's Balance of Payments and International Investment Position Manual, Sixth Edition (BPM6), paragraphs 6.86-6.92;

forward foreign exchange contract means a commitment to transact, at a designated future date and agreed-upon exchange rate, in a specified amount of specified foreign exchange (paragraph FD 28, Financial Derivatives, A supplement to the Fifth Edition (1993) of the IMF's Balance of Payments and International Investment Position Manual);

forward positions means predetermined short-term net drains on foreign currency assets in the form of forwards, futures, and swaps, as defined in Item II.2 of the Reserves Data Template in the IMF International Reserves and Foreign Currency Liquidity: Guidelines for a Data Template (2013);

imports means all goods that add to the stock of material resources of a country by entering its economic territory (International Merchandise Trade Statistics: Concepts and Definitions 2010, Chapter I, section A 1.2 of the United Nations);

intervention means the purchase or sale, or the purchase or sale of a forward position, under the direction of an exchange rate authority, of foreign exchange reserves involving the currency of the intervening Party and at least one other currency;

portfolio capital flows means cross-border transactions and positions involving debt or equity securities, other than those included in direct investment or reserve assets, as defined in the IMF's Balance of Payments and International Investment Position Manual, Sixth Edition (BPM6), paragraphs 6.54-6.57;

principal representative of a Party means a senior official of the exchange rate or fiscal or monetary authority of a Party; ${ }^{1}$ and

spot foreign exchange market means the foreign exchange market in which participants transact for immediate delivery.

\section{Article 33.2: General Provisions}

1. The Parties affirm that market-determined exchange rates are fundamental for smooth macroeconomic adjustment and promote strong, sustainable, and balanced growth.

\footnotetext{
${ }^{1}$ For greater certainty, the principal representatives of Mexico include a senior officer of the Ministry of Finance and Public Credit and a senior officer of the Central Bank.
} 
2. The Parties recognize the importance of macroeconomic stability in the region to the success of this Agreement and that strong economic fundamentals and sound policies are essential to macroeconomic stability, and contribute to strong and sustainable growth and investment.

3. The Parties share the objective of pursuing policies that strengthen underlying economic fundamentals, foster growth and transparency, and avoid unsustainable external imbalances.

\section{Article 33.3: Scope}

This Chapter does not apply with respect to the regulatory or supervisory activities or monetary and related credit policy and related conduct of an exchange rate or fiscal or monetary authority of a Party. ${ }^{2}$

\section{Article 33.4: Exchange Rate Practices}

1. Each Party confirms that it is bound under the IMF Articles of Agreement to avoid manipulating exchange rates or the international monetary system in order to prevent effective balance of payments adjustment or to gain an unfair competitive advantage.

2. Each Party should:

(a) achieve and maintain a market-determined exchange rate regime;

(b) refrain from competitive devaluation, including through intervention in the foreign exchange market; and

(c) strengthen underlying economic fundamentals, which reinforces the conditions for macroeconomic and exchange rate stability.

3. Each Party should inform promptly another Party and discuss if needed when an intervention has been carried out by the Party with respect to the currency of that other Party.

\section{Article 33.5: Transparency and Reporting}

1. Each Party shall disclose publicly:

${ }^{2}$ For greater certainty, the term "exchange rate or fiscal or monetary authority of a Party" includes a central bank of a Party. 
(a) monthly foreign exchange reserves data and forward positions according to the IMF's Data Template on International Reserves and Foreign Currency Liquidity, no later than 30 days after the end of each month;

(b) monthly interventions in spot and forward foreign exchange markets, no later than seven days after the end of each month;

(c) quarterly balance of payments portfolio capital flows, no later than 90 days after the end of each quarter; and

(d) quarterly exports and imports, no later than 90 days after the end of each quarter.

2. Each Party shall consent to the public disclosure by the IMF of:

(a) each IMF Article IV Staff Report on the country of the Party, including the exchange rate assessment, within four weeks of the IMF Executive Board discussion; and

(b) confirmation of the Party's participation in the IMF COFER database.

3. If the IMF does not disclose publicly any items listed in paragraph (2) with respect to a Party, that Party shall request that the IMF disclose publicly those items.

\section{Article 33.6: Macroeconomic Committee}

1. The Parties hereby establish a Macroeconomic Committee composed of principal representatives of each Party. Article 30.2.2(b) (Functions of the Commission) does not apply to the Macroeconomic Committee.

2. The Macroeconomic Committee shall monitor the implementation of this Chapter and its further elaboration.

3. The Macroeconomic Committee shall meet within one year after the date of entry into force of this Agreement, and at least annually thereafter, unless the Parties decide otherwise.

4. The Macroeconomic Committee shall, at each annual meeting, consider:

(a) the macroeconomic and exchange rate policies of each Party, and their consequences on diverse macroeconomic variables, including domestic demand, external demand, and the current account balance;

(b) issues, challenges, or efforts to strengthen capacity with respect to transparency or reporting; and 
(c) undertaking other activities as the Macroeconomic Committee may decide.

5. At each annual meeting, or as necessary, the Macroeconomic Committee may consider whether any provisions of this Chapter, except Article 33.3 (Scope), should be amended to reflect changes in monetary policy and the financial markets or should be interpreted. A decision by consensus of the Macroeconomic Committee that a provision of this Chapter should be amended shall be deemed to be a decision by consensus of the Commission to amend the provision. Amendments shall enter into force as provided for in Article 34.3 (Amendments). An interpretation issued pursuant to a decision by consensus of the Macroeconomic Committee shall be deemed to be an interpretation issued pursuant to a decision by consensus of the Commission.

6. The Commission shall not take any decision to amend or interpret a provision of this Chapter except as provided in paragraph 5.

\section{Article 33.7: Principal Representative Consultations}

1. A principal representative of a Party may request expedited bilateral consultations with a principal representative of another Party with respect to policies or measures of another Party that the principal representative of the requesting Party considers associated with competitive devaluation, the targeting of exchange rates for competitive purposes, fulfillment of the transparency and reporting commitments in Article 33.5 (Transparency and Reporting), or any other issue that the principal representative of the Party may wish to raise with respect to Articles 33.4 (Exchange Rate Practices) or 33.5 (Transparency and Reporting). A Party engaged in bilateral consultations may invite the Party not engaged in those consultations to participate and provide input.

2. If a principal representative of a Party requests bilateral consultations, the principal representatives (or their designees) of the consulting Parties shall meet within 30 days of the request to arrive at a mutually satisfactory resolution of the matter within 60 days of their initial meeting.

3. If a principal representative of a Party requests bilateral consultations with respect to another Party's fulfillment of the transparency and reporting commitments in Article 33.5 (Transparency and Reporting), whether circumstances disrupted the practical ability of the other Party to disclose publicly the items listed in that Article shall be taken into account in the consultations, with the objective of arriving at a mutually satisfactory resolution of the matter.

4. If there is failure to arrive at a mutually satisfactory resolution in any consultations under this Article, the consulting Parties may request that the IMF, consistent with its mandate:

(a) undertake rigorous surveillance of the macroeconomic and exchange rate policies and data transparency and reporting policies of the requested Party; or 
(b) initiate formal consultations and provide input, as appropriate.

\section{Article 33.8: Dispute Settlement}

1. A Party may have recourse to dispute settlement under Chapter 31 (Dispute Settlement), as modified by this Article, only with respect to a claim that a Party has failed to carry out an obligation under Article 33.5 (Transparency and Reporting) in a recurring or persistent manner and has not remediated that failure during consultations under Article 33.7 (Principal Representative Consultations). ${ }^{3}$

2. When selecting panelists to compose a panel under Article 31.9 (Panel Composition), each disputing Party shall select panelists so that each panelist:

(a) has served as a senior official of an exchange rate or fiscal or monetary authority of a Party or the International Monetary Fund; and

(b) meets the qualifications set out in paragraphs (2)(b) through (2)(d) of Article 31.8 (Roster and Qualification of Panelists).

3. A panel established under Article 31.6 (Establishment of a Panel) to make a determination as to whether a Party has failed to carry out an obligation under Article 33.5 (Transparency and Reporting) in a recurring or persistent manner and has not remediated that failure during consultations under Article 33.7 (Principal Representative Consultations) and a panel reconvened to make a determination on the proposed suspension of benefits, in accordance with Article 31.19 (Non-Implementation - Suspension of Benefits), may seek the views of the IMF in accordance with Article 31.15 (Role of Experts).

4. When a panel's determination is that a Party has failed to carry out an obligation under Article 33.5 (Transparency and Reporting) in a recurring or persistent manner, and has not remediated that failure during consultations under Article 33.7 (Principal Representative Consultations), the complaining Party may not suspend benefits that are in excess of benefits equivalent to the effect of that failure. In suspending benefits under Article 31.19 (NonImplementation - Suspension of Benefits), the complaining Party may take into account only the failure to carry out an obligation under Article 33.5 (Transparency and Reporting) and not any other action or alleged failure by the responding Party.

\footnotetext{
${ }^{3}$ For greater certainty, this Article does not provide a basis for any matter arising under any other provision of this Agreement, including Article 31.2(c) (Scope).
} 